\title{
Macro-Nutrient Intakes, Nutritional Status, and Menstrual Disorders of Adolescent Girls at Islamic Boarding School in Bone District
}

\author{
Rahayu Indriasari ${ }^{1}$, Ealdryani ${ }^{2}$,Devintha Virani ${ }^{3}$, Sabaria Manti $^{4}$, Healthy Hidayanti ${ }^{5}$, \\ Masni Mappajanci ${ }^{6}$ \\ \{rahayu.indriasari@unhas.ac.id ${ }^{1}$, ealdryani@gmail.com², devinthavirani@gmail.com³ \\ sabariamanti@gmail.com ${ }^{4}$, hhidayanty@yahoo.com ${ }^{5}$, masnimappajanci@ rocketmail.com ${ }^{6}$ \} \\ Departemen Gizi, Fakultas Kesehatan Masyarakat, Universitas Hasanuddin, Jl. Perintis Kemerdekaan \\ Km 10, Tamalanrea, Makassar, Sulawesi Selatan, 90245 Indonesia $^{1.3-6}$ \\ Departemen Kesmas, Fakultas Kesehatan Masyarakat, Universitas Hasanuddin, Jl. Perintis \\ Kemerdekaan Km 10, Tamalanrea, Makassar, Sulawesi Selatan, 90245 Indonesia $^{2}$
}

\begin{abstract}
Both under- and over-nutrition problems exist among Indonesian adolescent girls which was around $7.5 \%$ at aged $16-18$ years was thin, and $5.7 \%$ was obese. The problem of the menstrual disorder is also common among adolescent girls as $13.5 \%$ of Indonesian women aged 10-59 years had an irregular menstrual cycle. This research aims to investigate the relationship between nutritional status and macronutrient intake and menstrual disorders at adolescent girls. The study design was a cross-sectional with chisquare test. A total of 114 convenience sample was recruited from high school girls at grade 1 and 2 who attended Islamic Boarding School. The collected data was macronutrient intakes, body weight, height, and menstrual disorders which respectively using a semi-quantitative food frequency questionnaire, a weighing scale and a microtoice, and a self-administrative questionnaire. The results showed that the majority of school girls reported menstrual disorders $(61.4 \%)$. A significant relationship between inadequate fat intake and menstrual disorders $(\mathrm{p}=0,033)$ was discovered. Meanwhile, no significant relationship was found between carbohydrate intake $(\mathrm{p}=0,348)$, protein intake $(\mathrm{p}=0,667)$, and nutritional status $(\mathrm{p}=0,178)$ and menstrual disorders. The researchers concluded that inadequate macronutrient intakes and menstrual disorders could be the critical nutrition and reproductive health issues to be addressed among adolescent girls at a boarding school setting.
\end{abstract}

Keywords: Macro-nutrients, menstrual disorder, adolescent girls, boarding school

\section{Introduction}

Adolescents are experiencing cognitive, emotional, and social development, which affect all of their life aspects and functions [1]. Moreover, adolescents are also experiencing biological changes, such as body mass and body fat increase and hormonal changes. Therefore, adolescents are vulnerable to nutrition problems. Nutrition problems during adolescence are resulting a negative impact to a general population health condition which is caused by their short term impacts, such as, poor academic performance and low body immune, as well as their long term impacts, such as the increased risk of low birth weight [2]. 
Recent studies show that Indonesian adolescents are experiencing the dual burden of malnutrition with the coexistence of undernutrition and over nutrition problems. Based on Indonesian National Health Survey in 2013, 7.5\% of Indonesian adolescents aged 16-18 years old were underweight, while $5.7 \%$ of adolescents were overweight [3]. Undernutrition remains a common problem, especially in the eastern part of Indonesia as well as in the rural area. South Sulawesi, a province in eastern Indonesia, shows a higher prevalence of undernutrition compared to national prevalence. About $9.5 \%$ of adolescents in South Sulawesi were underweight, while $4.9 \%$ of adolescents were overweight [3]. High prevalence of undernutrition was also found in Bone Regency, one of the rural areas in South Sulawesi. In Bone, $9.4 \%$ of adolescents were underweight, while $7.2 \%$ of adolescents were overweight [3].

Due to hormonal changes during adolescence, girls are prone to several reproductive health problems, one of them is menstrual disorder. An Indonesian National Health Survey in 2013 shows that $13.7 \%$ of Indonesian girls aged 10-59 years old were experiencing menstrual cycle disorder, while in South Sulawesi, the prevalence was $14.5 \%$ in adolescents [4]. Menstrual disorders in adolescents have been associated with macro nutrition intake. Carbohydrate intake is associated with total calories during the luteal phase, while protein intake associated is with follicular phase period, and fat intake is associated with reproductive hormones [5]. The previous study in Jakarta, Indonesia, shows that $83.2 \%$ of adolescents had inadequate carbohydrate intake, and $61.5 \%$ of them were experiencing menstrual cycle disturbance [6]. Inadequate protein intake was found in $65 \%$ of respondents, and $53 \%$ of them were having an abnormal menstrual cycle [6]. Furthermore, $56.6 \%$ of respondents had inadequate fat intake and $47 \%$ of them experiencing an abnormal menstrual cycle [6]. In addition, menstrual disorders are also affected by other nutritional factors such as nutritional status and systemic disorder in very underweight or obese girls [7], [8].

Boarding schools play a crucial role in providing a nutritious meal for their students. However, often, little attention is paid to the adequacy of nutrition contents of the meals, which put the students at risk to nutritional and health problem. Furthermore, school meals provided in boarding schools sometimes do not meet students' preferences in which could affect their eating habit and later on their nutritional status. Therefore, this study aims to determine the association of macro nutrition intake and nutritional status with menstrual disorders among adolescent girls in Darul Huffadh Islamic Boarding School in Bone Regency.

\section{Method}

A cross-sectional study was undertaken among adolescent girls attending an Islamic Boarding School at Kajuara district, Bone, in South Sulawesi Province. The sample was recruited from high school girls at grade 1 and 2. Data collection was conducted in May 2018 among 114 female students at school. Anthropometric measurements were undertaken to assess nutritional status by measuring body weight using a digital weighing scale and measuring height using microtome. The menstrual disorder was measured using a selfadministered questionnaire and assessed using three criteria: 1) length of the menstrual cycle, 2) length of menstruation period, and 3) volume of menstrual blood. Demographic characteristics were also obtained through the questionnaire. Food consumption data during the latest one month was collected using a semi-quantitative food frequency questionnaire. Macronutrient intakes then were calculated based on food consumption data using Nutrisurvey software. Nutritional status was assessed using Body Mass Index by Age (BMI/A) with Zscore cutoff points. Relationships between variables were tested using Chi-Square. 


\section{Results}

Majority of adolescents were 16 years old (44.7\%), 15 years old (22\%), and 18 years old (8.8\%). Most students had adequate carbohydrate intake. Total of $60.5 \%$ of adolescents had adequate carbohydrate, which means their daily intake has fulfilled $80-110 \%$ recommended daily intake (RDA). However, $23.7 \%$ of adolescents were found had inadequate carbohydrate intake ( $<80 \%$ RDA). Only $45.6 \%$ of adolescents met the recommendation of daily protein intake, and $36.8 \%$ of them had inadequate protein intake. On the other hand, many adolescents had an excess daily fat intake, with a total number of $48.2 \%$. Total of $35.1 \%$ of students has adequate fat intake (Table 1).

Table 1. Micronutrient Intake, Nutritional Status, and Menstrual Disorder of Adolescent Girls at Daarul Huffadh Islamic Boarding Schools

\begin{tabular}{llcc}
\hline Micronutrient intake & & $\mathbf{n}$ & $\mathbf{\%}$ \\
\hline Carbohydrate & Inadequate & 27 & 23.7 \\
& Adequate & 69 & 60.5 \\
Protein & Exceed & 18 & 15.8 \\
& Inadequate & 42 & 36.8 \\
Fat & Adequate & 52 & 45.6 \\
& Exceed & 20 & 17.5 \\
\multirow{3}{*}{ Nutritional Status } & Inadequate & 19 & 16.7 \\
& Adequate & 40 & 35.1 \\
& Exceed & 55 & 48.2 \\
Menstrual disorder & & $\mathbf{n}$ & $\mathbf{\%}$ \\
& Overweight & 18 & 15.8 \\
& Normal & 96 & 84,2 \\
& & $\mathbf{n}$ & $\mathbf{\%}$ \\
& & 70 & 61.4 \\
& Yes & 44 & 38.6 \\
& & $\mathbf{1 1 4}$ & $\mathbf{1 0 0}$ \\
\hline
\end{tabular}

Nutritional status was assessed based on BMI by age indicator. It was found that $84.2 \%$ of the students had normal nutritional status. No students were underweight, while $15.8 \%$ of students were overweight (Table 1). Based on the presence of at least one of three of menstrual disorders, it was found that there was $61.4 \%$ of adolescent girls experienced the menstrual disorder. Among these, $75.7 \%$ of adolescents had an abnormal menstrual cycle $(<21$ days or $>35$ days), $47.1 \%$ had an abnormal menstrual period ( $<2$ days or $>7$ days), and $50.0 \%$ experienced abnormal menstrual bleeding ( $<10 \mathrm{cc}$ or $>80 \mathrm{cc}$ per menstrual period).

Generally, it was found that adolescent with inadequate macronutrient intakes prone to experienced menstrual disorders. For those who had inadequate carbohydrate intake, there were more adolescent girls reported to had abnormal menstrual disorder compared to normal menstrual status $(70 \%$ vs. $30 \%$, respectively). This was true for inadequate protein and inadequate fat intake groups $(67 \%$ vs. $33 \%$, and $74 \%$ vs. $26 \%$, respectively) (Table 2). 
Table 2. Association of Macronutrient Intake with Menstrual Disorder among Adolescent Girls Menstrual disorder

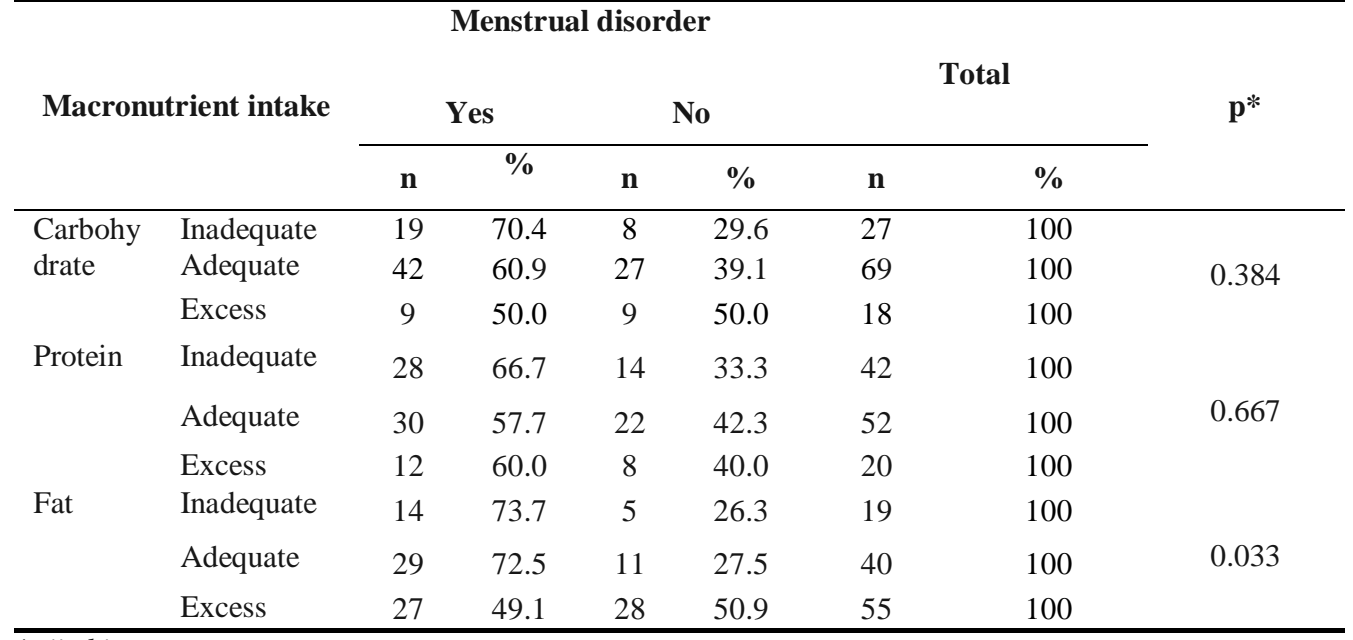

*uji chi-square

However, there was no significant association between carbohydrate and protein intake with menstrual disorders $(\mathrm{p}>0.05)$. There was a significant association between fat intake and menstrual disorder $(\mathrm{p}<0.05)$.

There was no association between nutritional status and menstrual disorder $(\mathrm{p}>0.05)$. Fewer overweight adolescents were reported they had abnormal menstruation (44\%) compared to the normal ones $(56 \%)$. On the other hand, more adolescent girls with normal weight were reported to had menstrual disorder than normal menstruation (65\% vs 35\%) (Table 3).

Table 3. Association of Nutritional Status with Menstrual Disorder among Adolescent Girls

\begin{tabular}{|c|c|c|c|c|c|c|c|}
\hline \multirow{3}{*}{ Nutritional Status } & \multicolumn{4}{|c|}{ Menstrual disorder } & \multirow{2}{*}{\multicolumn{2}{|c|}{ Total }} & \multirow{3}{*}{$\mathbf{p}^{*}$} \\
\hline & \multicolumn{2}{|c|}{ Yes } & \multicolumn{2}{|c|}{ No } & & & \\
\hline & $\mathbf{n}$ & $\%$ & $\mathbf{n}$ & $\%$ & $\mathbf{n}$ & $\%$ & \\
\hline Overweight & 8 & 44.4 & $\overline{10}$ & 55.6 & 18 & 100 & 0178 \\
\hline Normal & 62 & 64.6 & 34 & 35.4 & 96 & 100 & $0.1 / 8$ \\
\hline
\end{tabular}

\section{Discussion}

Our study found that there was a high percentage of adolescent girls who had inadequate daily macronutrient intake. However, there was no underweight girl found in this study, and some adolescents were found overweight (15.8\%). The percentage of overweight girls found in this study was higher than the overweight prevalence in Bone Regency and South Sulawesi Province. Compared to the previous study in Jakarta, an urban city in Indonesia, our study shows better macronutrient intake and nutritional status of adolescent girls. The difference in these results might be affected by the setting and context of the population.

Our study found that there were many students who had the menstrual disorder, especially irregular menstruation cycle. This finding is considered normal as adolescents in this present 
study were experiencing menarche at the age 13-14 years old, and most of our respondents were 16-17 years old when the study was conducted. The previous study by Fujiwa, et al., suggested that about $25-40 \%$ of girls were experiencing irregular menstruation or did not ovulate until four years after menarche because positive estrogen feedback system on hypothalamus and pituitary is still developing [9]. However, we found that the second common disturbance reported by the girls in this present study was abnormal blood volume $(50 \%)$ and around $50 \%$ girls reported to have at least two types of menstrual disorder.

Poor diet, in general, might be closely related to hormonal changes during the menstrual cycle leading to menstrual disorder. This study found a high number of inadequate macronutrient intakes. However, there was no significant association of both carbohydrate and protein intake with menstrual disorder. It was found that many adolescents with adequate and excess carbohydrate and protein intake also experienced the menstrual disorder. The previous study in a similar setting found that more adolescents with the menstrual disorder had inadequate carbohydrate and protein intake [10]. In contrast, the previous study found a significant relationship between carbohydrate and menstrual disorders among high school students in Jakarta [6].

The insignificant difference in this present study might be caused by a monotonous dietary pattern of the adolescents in the boarding school since their meals were mainly provided by the boarding school. On the other hand, adolescents in a public high school setting mainly have their meals at home. Therefore, their meals are more diverse compared to students in boarding school.

Only a few of adolescents were found had an inadequate fat intake, while $48 \%$ of adolescents had daily fat intake more than RDA. Snacks, such as fried banana, vegetable fritters (bakwan), fried tofu, and fried tempeh, were the biggest contributors to the adolescents' fat intake. The bivariate analysis shows a significant association of fat intake and menstrual disorders among adolescents in this Islamic boarding school. Similar findings were found in previous studies by Sitoayu (2017) and Hidayah (2016) who found a significant association of fat intake and menstrual disorder [6], [10]. Moreover, Sitoayu (2017) found higher consumption of animals-based side dishes compared to vegetables-based side dishes. The most frequently consumed animal-based side dish was chicken (32.9\%) and most often served as fried chicken $(16.3 \%)$. The most frequently consumed vegetable side dish was tempeh $(3.9 \%)$ and most often served as fried tempeh $(2.1 \%)$.

On the other hand, our findings found that adolescents in Bone consumed vegetable side dishes (tofu and tempeh) more frequently than animals side dishes, such as beef meat, chicken, fish, and egg. This might contribute to the menstrual disorders of adolescent girls. The previous study found that lower consumption of fish, eggs, and fruit was a risk factor for dysmenorrhea, early menarche, and long and heavy menstrual flow [11].

Despite the overweight adolescents found in this study, there was no significant association of nutritional status and menstrual disorder. This finding contrasts with previous studies by Sitoayu (2017) and Hidayah (2016) who found a significant association of nutritional status and menstrual disorders [6], [10]. The previous study in regular high school in Jakarta found that more normal and overweight girls were reported experiencing menstrual disorders [6]. On the other hand, the previous study in Islamic boarding schools found that more underweight girls were reported to had abnormal menstruation cycle compared to those who had normal weight [10]. These findings were different from ours. Our study found that more normal weight girls were reported to had menstrual disorder (either abnormal menstrual cycle disorder, abnormal menstruation period, or abnormal blood volume and combination of these three disturbances) than overweight girls. 
Overnutrition in adolescent girls could cause menstrual disorder due to the increase of estrogen production. The continuous increase of estrogen could indirectly cause an increase in androgen hormone that could disturb the follicle development and lead to the failure of mature follicle production [12]. Among overweight girls, the total estrogen hormone increase as the result of the increase in body fat. High estrogen hormone gives a negative impact to the hormone GnRH secretion, which inhibits the secretion of FSH hormone by anterior hypophysis. The barrier in FSH hormone secretion disturbing the follicle development and failure of mature follicle production. This theory might explain the mechanism of the long menstruation cycle or late menstruation in overweight girls [12].

\section{Conclusion}

Many adolescent girls in Islamic boarding school had inadequate macronutrient intakes and experienced menstrual disorders. Therefore more preventive and curative action should be taken to overcome this problem. There are various risk factors of menstrual disorders. However, many of them were not explored in this study. Further research is needed to investigate the roles of both nutritional and non-nutritional factors to the menstrual disorders both in Islamic boarding schools setting and in regular schools.

\section{References}

[1] Adriani \& Wirjatmadi.: Peranan Gizi dan Siklus Kehidupan. Jakarta: Prenadamedia Group. pp. 45-55 (2012)

[2] Marmi.: Gizi dalam Kesehatan Reproduksi. Yogyakarta; Pustaka Pelajar. pp. 80-95.(2013)

[3] Kementerian Kesehatan RI.: Riset Kesehatan Dasar Tahun 2013. Jakarta; Kemenkes RI. pp.78-90. (2013)

[4] Kementrian Kesehatan RI.: Infodatin Pusat Data Dan Informasi Kesehatan RI Situasi Kesehatan Reproduksi Remaja. Jakarta; Pusat Data dan Informasi. pp. 89-96. (2013)

[5] Dieny.: Permasalahan Gizi Pada Remaja Putri. Yogyakarta; Graha Ilmu. pp. 67-92. (2014.)

[6] Sitoayu, L., Pertiwi, D.A., \&Mulyani, E.Y.: Kecukupan zat gizi makro, status gizi, stres, dan siklus menstruasi pada remaja. Jurnal Gizi Klinik Indonesia. Vol. 13, pp. 121-128. (2017)

[7] Kusmiran \& Eny.: Kesehatan Remaja dan Wanita. Jakarta; Salemba Medika. pp. 97-60. (2011)

[8] Jumiatun \& Arasta, L.D.: Hubungan Gangguan Menstruasi Dengan Kejadian Anemia Pada Remaja Putri Di SMPN 1 Rowosari Kabupaten Kendal. Jurnal Ilmu Kesehatan. Vol. 4, pp. 1-9. (2013)

[9] Tomoko Fujiwara, Natsuyo Sato, Hiroyo Awaji, and Rieko Nakata.: Adverse Effects of Dietary Habits on Menstrual Disorders in Young Women. The Open Food Science Journal. Vol. 1, pp. 2430. (2007)

[10] Hidayah, N., Rahfiludin, M.Z., \& Aruben, R.: Hubungan Status Gizi, Asupan Zat Gizi Dan Aktivitas Fisik Dengan Siklus Menstruasi Remaja Putri Pondok Pesantren Salafiyah Kauman Kabupaten Pemalang Tahun 2016. Jurnal Kesehatan Masyarakat. Vol. 4, pp. 2356-3346. (2016)

[11] Balbi C, Musone R, Menditto A.: Influence of menstrual factors and dietary habits on menstrual pain in adolescence age. European Journal of Obstetrics, Gynecology, and Reproductive Biology. Vol. 91, pp. 143-8. (2000)

[12] Wei S,.: Obesity and menstrual irregularity: associations with SHBG, testosterone and insulin. Vo;. 1.pp. 161-7. (2009) 
